\title{
Delphi consensus on the diagnosis and treatment of patients with short stature in Spain: GROW-SENS study
}

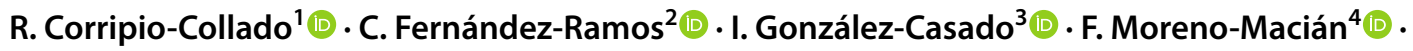 \\ J.-P. López-Siguero ${ }^{5}$ (D) J.-I. Labarta-Aizpún ${ }^{6,7}$ (i)
}

Received: 23 September 2021 / Accepted: 21 October 2021 / Published online: 17 November 2021

(c) The Author(s) 2021

\begin{abstract}
Purpose To identify consensus aspects related to the diagnosis, monitoring, and treatment of short stature in children to promote excellence in clinical practice.

Methods Delphi consensus organised in three rounds completed by 36 paediatric endocrinologists. The questionnaire consisted of 26 topics grouped into: (1) diagnosis; (2) monitoring of the small-for-gestational-age (SGA) patient; (3) growth hormone treatment; and (4) treatment adherence. For each topic, different questions or statements were proposed.

Results After three rounds, consensus was reached on 16 of the 26 topics. The main agreements were: (1) diagnosis tests considered as a priority in Primary Care were complete blood count, biochemistry, thyroid profile, and coeliac disease screening. The genetic test with the greatest diagnostic value was karyotyping. The main criterion for initiating a diagnostic study was prediction of adult stature 2 standard deviations below the target height; (2) the main criterion for initiating treatment in SGA patients was the previous growth pattern and mean parental stature; (3) the main criterion for response to treatment was a significant increase in growth velocity and the most important parameter to monitor adverse events was carbohydrate metabolism; (4) the main attitude towards non-responding patients is to check their treatment adherence with recording devices. The most important criterion for choosing the delivery device was its technical characteristics.

Conclusions This study shows the different degrees of consensus among paediatric endocrinologists in Spain concerning the diagnosis and treatment of short stature, which enables the identification of research areas to optimise the management of such patients.
\end{abstract}

Keywords Adherence $\cdot$ Delphi $\cdot$ Diagnosis $\cdot$ Growth hormone $\cdot$ Monitoring $\cdot$ Short stature

R. Corripio-Collado, C. Fernández-Ramos, I. González-Casado, F. Moreno-Macián, J.-P. López-Siguero, and J.-I. Labarta-Aizpún are equally credited authors.

\section{J.-I. Labarta-Aizpún}

jilabarta@salud.aragon.es

R. Corripio-Collado

rcorripio@tauli.cat

C. Fernández-Ramos

conchi.fernandezramos@osakidetza.eus

I. González-Casado

isabelgcasado@gmail.com

F. Moreno-Macián

morenoframac@gmail.com

J.-P. López-Siguero

lopez.siguero@gmail.com

1 Paediatric Endocrinology Unit, Hospital Universitario Parc Taulí, Sabadell, Barcelona, Spain
2 Paediatric Endocrinology Unit, Hospital Universitario Basurto, Bilbao, Spain

3 Pediatric Endocrinology Deparment, Hospital Universitario La Paz, Madrid, Spain

4 Paediatric Endocrinology Unit, Hospital Universitario y Politécnico La Fe, Valencia, Spain

5 Paediatric Endocrinology Unit, Hospital Regional Universitario de Málaga, Instituto de Investigación de Málaga (IBIMA), Malaga, Spain

6 Paediatric Endocrinology Unit, Paediatric Department., Hospital Universitario Miguel Servet, Instituto de Investigación Sanitaria de Aragón, Zaragoza, Spain

7 Department of Microbiology, Pediatrics, Radiology, and Public Health. School of Medicine, Zaragoza University, Avenida Isabel la Catolica 1-3, 50009 Zaragoza, Spain 


\section{Introduction}

Short stature is one of the main reasons for paediatric consultation [1]. Hence, the importance of making a correct assessment allows the diagnostic process to be properly directed. Although there is no international consensus defining normal versus pathological growth, the most frequently used criteria for short stature or abnormal growth are as follows: (a) height below -2 standard deviations (SD) for age and sex on growth curves corresponding to the population studied; (b) normal height (between $\pm 2 \mathrm{SD}$ ), but $2 \mathrm{SD}$ below target height; (c) estimated adult stature below -2 SD of target height; and (d) reduced growth velocity, below $-1 \mathrm{SD}$ (25th percentile) for age and sex, maintained over a period of 1 year or, in the absence of short stature at a growth velocity less than -2 SD [1-5]. The choice of appropriate growth curves is very important in growth assessment and the use of updated national curves is recommended [6-8].

There is different terminology used to classify short stature, but, in general, all of it can be divided into pathological or known-cause short stature and idiopathic or unknowncause short stature $[1,5]$. Idiopathic short stature has been extensively reviewed, and its concept has been debated and discussed in recent years. Differentiation between idiopathic short stature and idiopathic growth hormone $(\mathrm{GH})$ deficiency is often difficult and reflects the poor discriminating power of somatotropic axis tests, since many patients diagnosed with short stature are variants of normal growth $[1,5]$.

Since there is little uniformity in the criterion for management of short stature, this study has been proposed to evaluate clinical practice in the management of short stature in Spain and show the degree of consensus in the management of this pathology.

\section{Methods}

\section{Study design}

The GROW-SENS study was conducted using a modified Delphi method of quantitative, semi-quantitative, and qualitative analyses. This is a structured, group communication technique whereby written online surveys can be conducted to collect and unify the opinions of a group of experts about a complex or controversial topic with insufficient scientific evidence. This technique avoids the difficulties and drawbacks inherent to consensus methods based on face-to-face discussion, such as travel, influence biases, and non-confidential interaction $[9,10]$.

The process was carried out in four phases: (1) creation of a scientific committee in charge of the project;
(2) kick-off meeting to propose the main topics through a review of the latest literature evidence; (3) three successive rounds of online surveys to gather the opinions of a panel of experts; and (4) analysis of the results and discussion of the conclusions by the scientific committee.

\section{Participants}

The scientific committee coordinated the entire consensus and was made up of six national experts in paediatric endocrinology. The panel of participating experts was selected by the scientific committee and included 56 paediatric endocrinologists from different Spanish provinces. The set of panellists had a minimum of 10 year experience as paediatricians mainly specialising in paediatric endocrinology and they were all members of the Spanish Paediatric Endocrinology Society (SEEP). The panellists were invited to participate in the study by e-mail, informing them of the nature of the study through a presentation letter.

\section{Questionnaire}

At the kick-off meeting, the scientific committee discussed the main strategies for the diagnosis and treatment of short stature. As a result of this meeting, 26 topics were proposed, grouped into four blocks: (1) diagnosis; (2) monitoring of the small-for-gestational-age (SGA) patient with short stature; (3) GH treatment; and (4) treatment adherence. For each block, several questions or statements were proposed which, depending on the type of response, could be dichotomous, multi-response, qualitative, quantitative, and, often, Likert scale.

The Likert scale used consisted of 11 items grouped as follows: 0-2, interpreted as not at all important or strongly disagree; 3-4, interpreted as slightly important or disagree; 5-6, interpreted as important or neither agree nor disagree; $7-8$, interpreted as very important or agree; and 9-10, interpreted as extremely important or strongly agree.

\section{Delphi consensus}

Consensus was reached in three rounds of consultations held between March 2019 and March 2020. In the first round, the participants answered the online questionnaire with the possibility of adding their opinion with open text. Following analysis of the answers provided, the questions were rephrased in the second round and then again in the third round. The results of the three rounds were tabulated and presented in a descriptive form to be analysed, interpreted, and discussed jointly by the scientific committee to find common ground and provide useful conclusions and recommendations for the clinical practice of paediatric endocrinologists. 


\section{Analysis and interpretation of the results}

The data analysed provided semi-quantitative information (scores of the responses collected through Likert scales) and qualitative information (analysis of the experts' discourse in open-ended questions). A minimum of $70 \%$ of homogeneous responses was established to consider that there was consensus among the panel of experts on the answer to this question.

\section{Ethical considerations}

All the recommendations set out in the Helsinki declaration were used. All participants gave informed consent and no personal information was recorded at any time. To preserve the confidentiality of the opinions, all information was coded.

\section{Results}

Out of the 56 endocrinologists recruited, 43 completed the first round, 37 completed the second round, and $36 \mathrm{com}-$ pleted all three rounds of the study. Out of the 26 items proposed, consensus was reached on 16 of them (61.5\%). Tables 1, 2, 3, and 4 show the topics dealt within each block and the degree of consensus reached on those that exceeded $70 \%$.

\section{Block 1: diagnosis of short stature}

Out of the 13 proposed topics on the diagnosis of short stature, consensus was reached on 8 of them (61.5\%). The topic with the highest degree of consensus (100\%) was tests considered to be of priority use in Primary Care. Participants agreed that the tests should be complete blood count, biochemical analyses, thyroid function, and screening for coeliac disease.

Another topic with a high degree of consensus was the diagnostic value of genetic testing. $98 \%$ of the specialists considered karyotyping to be of important diagnostic value. The SHOX gene sequencing study was considered an additional test by $80 \%$ of panellists. Exome sequencing and study of bone dysplasias are never performed or are infrequent according to $89 \%$ and $76 \%$ of respondents, respectively. $65 \%$ agreed that performing genetic testing for Noonan syndrome is very rare or never performed.

Among the diagnostic criteria for study of short stature with the highest degree of consensus are the prediction of adult stature 2 SD below the target height (94\%) and a growth velocity $\leq-1$ SD for more than 1 year (76\%). There was consensus on the method of how the calculation of a patient's adult stature prognosis is performed, with the majority of specialists (89\%) mentioning that they use bone age to establish it. $72 \%$ of the experts use the Spanish Crosssectional Growth Study 2010 as a reference standard.

A high percentage of the specialists (86\%) did not agree that GH stimulation tests are a decisive test in the diagnosis of GH deficit and $72 \%$ consider that it is not necessary to perform two tests to diagnose an isolated GH deficit.

No consensus was reached concerning the following topics: most appropriate cut-off point to establish a diagnosis of GH deficit; the need to perform, at this time, a national growth study to establish the reference standards for the Spanish population; use of gonadal steroid priming testing at peripubertal ages; the approach that should be taken in a 13-year-old male patient with a testicular volume of $3 \mathrm{ml}$ and decreased growth velocity; and the clinical conditions that may cause short stature under which a GH deficiency study should be performed.

The results obtained from the scores the panellists gave to the statements proposed in block 1 are presented in Table 1 .

\section{Block 2: small-for-gestational-age patient}

Regarding the block on monitoring the SGA patient, consensus was reached on two of the three topics proposed (66.7\%). The main criteria considered indispensable for starting GH treatment in these patients were: length and weight at birth (95\%), stature at 4 years (94\%), previous growth pattern (100\%), and mean parental stature (97\%).

In SGA patients, most specialists (88\%) did not consider Silver-Russell syndrome to be an exclusion criterion for initiating GH treatment. There was no consensus concerning the appropriate age for the initiation of GH treatment in the non-recovering SGA patient.

The results obtained from the scores the panellists gave to the statements in block 2 are presented in Table 2.

\section{Block 3: GH treatment}

Of the 6 proposed topics on GH treatment, consensus was reached on 3 of them (50\%). For monitoring of adverse events resulting from $\mathrm{GH}$ treatment, in addition to thyroid function tests, bone age, and IGF-I levels, the participants stated that the most important tests are the assessment of carbohydrate metabolism (100\%) and lipid metabolism (78\%).

Regarding the attitude towards a non-responding patient, the most recommended sequence of action (76\%) was: (1) check treatment adherence; (2) increase the dose; (3) reconsider the diagnosis; (4) assess comorbidities; and (5) discontinue treatment.

The parameter with the highest consensus for assessing response to $\mathrm{GH}$ treatment in patients with short stature was a significant increase in growth velocity (73\%). 


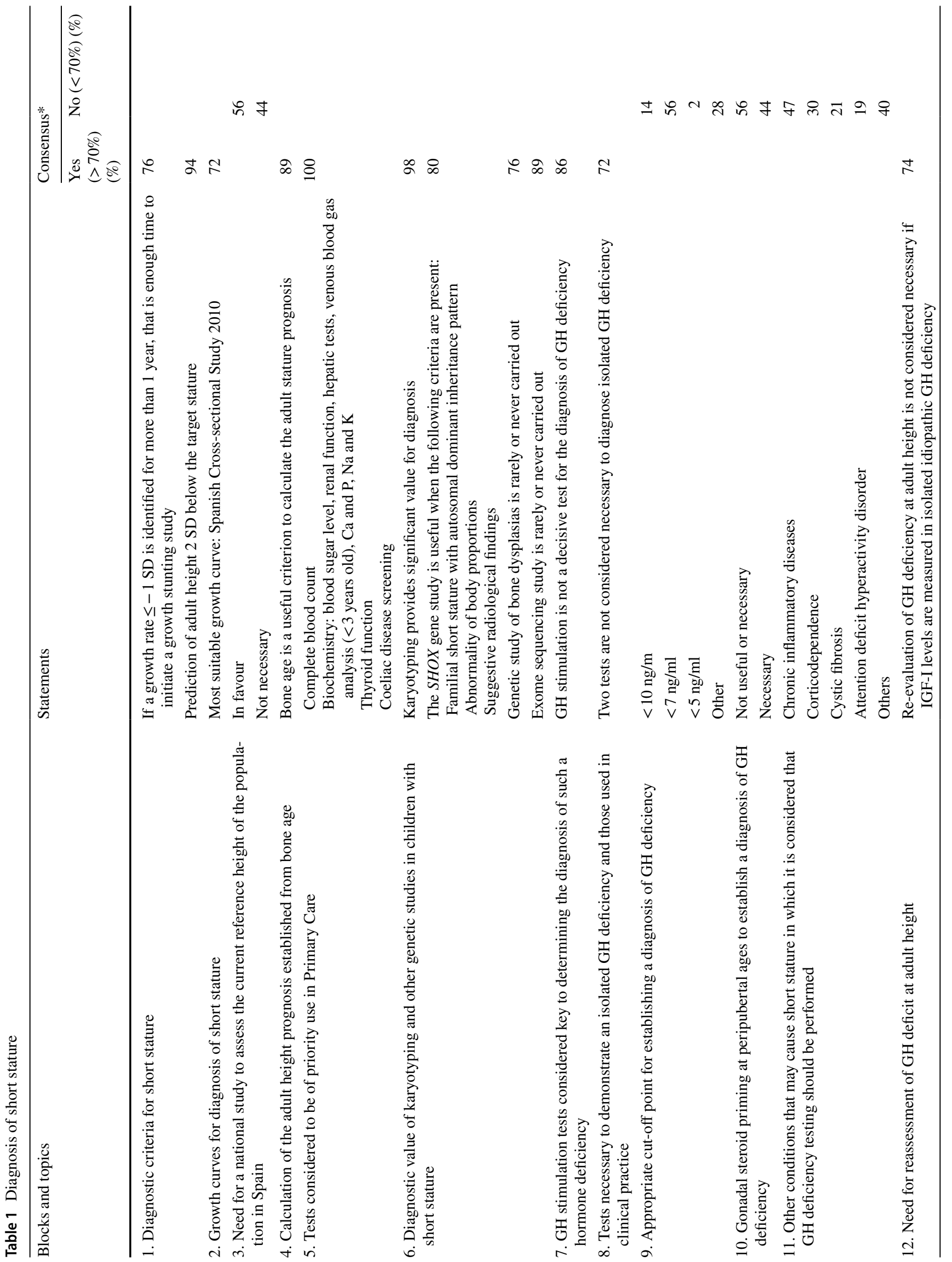


Only $22 \%$ of participants are free to prescribe any $\mathrm{GH}$, $50 \%$ can only choose between two or three options, and for $28 \%$, the administration chooses the treatment.

There was no consensus concerning either the age for the initiation of GH treatment in children with Prader-Willi syndrome or the waiting time for an oncological patient to start GH treatment after the start of remission.

The results obtained from the scores the panellists gave to the statements in block 3 are presented in Table 3.

\section{Block 4: treatment adherence}

In the block on treatment adherence, out of the four topics proposed, consensus was reached on three. Regarding the criteria for a personalised choice of GH delivery device, the specialists indicated the following as the most important: technical characteristics of the device (97\%), drug data sheet (73\%), hospital criteria (70\%), and user preferences (70\%).

The resources that specialists considered most important for monitoring adherence to $\mathrm{GH}$ treatment were: use of electronic recording devices (97\%), health education (95\%), nursing support (86\%), and new e-health technologies $(84 \%)$.

94\% considered the child's self-esteem to be an element favouring adherence.

There was no consensus concerning the prioritisation of resources to monitor treatment adherence.

The results obtained from the scores the panellists gave to the statements in block 4 are presented in Table 4 .

\section{Discussion}

This is the first study in Europe with the Delphi method to assess the diagnosis and management of patients with short stature during childhood. The degree of consensus reached in this study was high: for 16 of the 26 topics proposed, it was higher than $70 \%$. Despite the existence of some expert consensus [1,5], many of the topics related to the diagnosis and treatment of short stature are still a matter of debate. The GROW-SENS study was designed with the aim of finding out the opinion of paediatric endocrinologists on these aspects. The Delphi method used in this paper in relation to short stature and GH is novel in this field.

\section{Block 1: diagnosis of short stature}

The prevalence of pathological short stature in children referred for assessment is around 5\% and varies between $1.3 \%$ and $19.8 \%$. There is significant variability in establishing when to initiate a short stature study [11-13]. There is no evidence-based consensus that determines the tests that must be performed in a study of a child with short stature 
Table 2 Small-for-gestational-age patient

\begin{tabular}{|c|c|c|c|}
\hline \multirow[t]{2}{*}{ Blocks and topics } & \multirow[t]{2}{*}{ Statements } & \multicolumn{2}{|c|}{ Consensus* } \\
\hline & & $\begin{array}{l}\text { Yes } \\
(>70 \%) \\
(\%)\end{array}$ & No $(<70 \%)(\%)$ \\
\hline \multirow{4}{*}{$\begin{array}{l}\text { 1. Information that should be essential for initiating GH treatment in } \\
\text { SGA patients }\end{array}$} & Length and weight at birth & 95 & \\
\hline & Height at 4 years & 94 & \\
\hline & Previous growth pattern & 100 & \\
\hline & Average parenteral size & 97 & \\
\hline $\begin{array}{l}\text { 2. Silver-Russell syndrome as an exclusion criterion for initiating GH } \\
\text { treatment in SGA patients }\end{array}$ & It is not considered an exclusion criterion & 88 & \\
\hline \multirow[t]{2}{*}{$\begin{array}{l}\text { 3. Appropriate age for initiation of GH treatment in the non-recovering } \\
\text { SGA patient }\end{array}$} & $\begin{array}{l}\text { From the age of } 2 \text { years, if the GH indica- } \\
\text { tion is authorised at that age }\end{array}$ & & 54 \\
\hline & $\begin{array}{l}\text { From the age of } 4 \text { years, even if there is } \\
\text { an indication from the age of } 2 \text { years }\end{array}$ & & 46 \\
\hline
\end{tabular}

$S D$ standard deviations, $G H$ growth hormone

*There is considered to be consensus when more than $70 \%$ homogeneous responses have been recorded

Table 3 Growth hormone treatment

\begin{tabular}{|c|c|c|c|}
\hline \multirow[t]{2}{*}{ Blocks and topics } & \multirow[t]{2}{*}{ Statements } & \multicolumn{2}{|l|}{ Consensus* } \\
\hline & & No $(<70 \%)(\%)$ & No $(<70 \%)(\%)$ \\
\hline \multirow{3}{*}{$\begin{array}{l}\text { 1. Most appropriate age for commencement of GH treatment in } \\
\text { a child with Prader-Willi syndrome }\end{array}$} & Before 2 years old & & 67 \\
\hline & Between 1 and 2 years & & 42 \\
\hline & From 2 years old & & 33 \\
\hline 2. Attitude towards a patient who does not respond to treatment & $\begin{array}{l}\text { The sequence that reflects a better attitude } \\
\text { on the part of the specialists is: } \\
\text { 1. Check treatment adherence } \\
\text { 2. Increase the dose } \\
\text { 3. Evaluate the diagnosis } \\
\text { 4. Assess comorbidities } \\
\text { 5. Discontinue treatment }\end{array}$ & 76 & \\
\hline \multirow{2}{*}{$\begin{array}{l}\text { 3. Attitude towards the approach to a child with GH deficiency } \\
\text { in the context of an oncological history: time considered } \\
\text { appropriate to wait to start GH administration from the onset } \\
\text { of remission, assuming that there are no contraindications and } \\
\text { that the oncologist and parents agree }\end{array}$} & Preferably before 2 years old & & 34 \\
\hline & Preferably after 2 years old & & 66 \\
\hline \multirow{2}{*}{$\begin{array}{l}\text { 4. Recommended tests, in addition to thyroid function, bone age } \\
\text { and IGF-I, to monitor for adverse events that may arise from } \\
\text { GH treatment }\end{array}$} & Carbohydrate metabolism test & 100 & \\
\hline & Lipid metabolism test & 78 & \\
\hline $\begin{array}{l}\text { 5. Most important parameters in the assessment of response to } \\
\text { GH treatment according to indications for treatment of short } \\
\text { stature }\end{array}$ & Significant increase in growth velocity & 73 & \\
\hline \multirow[t]{3}{*}{ 6. Freedom of GH prescription } & I can choose between two or three options & & 50 \\
\hline & It is up to the administration to decide & & 28 \\
\hline & I have freedom of prescription & & 22 \\
\hline
\end{tabular}

$S D$ standard deviations, $G H$ growth hormone

*There is considered to be consensus when more than $70 \%$ homogeneous responses have been recorded

[5] and the diagnostic yield of the tests used in children with short stature is very low [14].

Different authors propose conducting a karyotype in girls with short stature with an unexplained cause, shorter than their genetic stature or when they present two or more dysmorphic characteristics [15-18]. Within the scope of Primary Care, it is more common to request a complete blood count, general biochemical parameters, thyroid function, and 
Table 4 Treatment adherence

\begin{tabular}{|c|c|c|c|}
\hline \multirow[t]{2}{*}{ Blocks and topics } & \multirow[t]{2}{*}{ Statements } & \multicolumn{2}{|c|}{ Consensus* } \\
\hline & & $\begin{array}{l}\text { Yes } \\
(<70 \%) \\
(\%)\end{array}$ & No $(<70 \%)(\%)$ \\
\hline \multirow{4}{*}{$\begin{array}{l}\text { 1. Criteria for personalised choice of a GH delivery } \\
\text { device }\end{array}$} & Technical characteristics of the device & 97 & \\
\hline & Drug data sheet & 73 & \\
\hline & Hospital criteria & 70 & \\
\hline & User preferences & 70 & \\
\hline \multirow[t]{4}{*}{ 2. Resources for monitoring GH treatment adherence } & Use of recording devices & 97 & \\
\hline & Health education for children and parents & 95 & \\
\hline & Nursing support & 86 & \\
\hline & New technologies: SMS, Apps, e-Health & 84 & \\
\hline \multirow[t]{2}{*}{$\begin{array}{l}\text { 3. Priority resources for improving GH treatment adher- } \\
\text { ence }\end{array}$} & $\begin{array}{l}\text { 1st sequence: health education; nursing support; use of } \\
\text { recording devices; new technologies }\end{array}$ & & 50 \\
\hline & $\begin{array}{l}\text { 2nd sequence: health education; use of recording devices; } \\
\text { nursing support; new technologies }\end{array}$ & & 50 \\
\hline $\begin{array}{l}\text { 4. Influence of improved child self-esteem as a factor that } \\
\text { favours GH treatment adherence }\end{array}$ & $\begin{array}{l}\text { The child's self-esteem is a factor that favours GH treat- } \\
\text { ment adherence }\end{array}$ & 94 & \\
\hline
\end{tabular}

$S D$ standard deviations, $G H$ growth hormone

*There is considered to be consensus when more than $70 \%$ homogeneous responses have been recorded

screening for coeliac disease. It is estimated that $2-8 \%$ of children with non-familial short stature without gastrointestinal symptoms have coeliac disease [19-21], and this is in agreement with the findings of the study performed.

There was controversy as to whether it is advisable to request IGF-I serum levels in Primary Care, due to the difficulties of interpretation and the methodological variability involved. Determination of IGF-I should be the first test to be performed in Specialised Care to study the somatotropic axis, since an IGF-I higher than the 50th percentile associated with a growth velocity higher than the 25 th percentile makes a GH deficit highly unlikely [19, 22, 23].

Regarding the request for genetic tests other than karyotyping, study of the SHOX gene was the most requested by the participants, especially in the case of familial short stature with autosomal dominant inheritance pattern, abnormalities in body proportions, and/or suggestive radiological findings.

It should be noted that assessments expressed by participants concerning each genetic test reflect the frequency with which those tests are requested, which may be influenced not only by clinical judgement, but also by availability. The benefit of genetic studies to diagnose short stature increases when they are associated with systematic phenotyping of patients [24].

Regarding the criteria for diagnosing short stature, participants clarified that an isolated height measurement is not sufficient and needs to be verified by successive calculations. It was also clarified that although an extreme growth velocity and short stature (below $-2.5 \mathrm{SD}$ ) with poor prognosis for adult stature are two important criteria for the diagnosis of pathological short stature, if the parents' values are very different, this indicator loses sensitivity.

Most of the specialists interviewed considered that the most appropriate growth curve is that in the Spanish Crosssectional Study 2010 [25, 26]. In spite of this, some of the panellists said that other Spanish curves are also occasionally used [6, 27].

Although it was not considered a priority to carry out a national study to assess the reference stature of the Spanish population, the general recommendation is to do so every 10-15 years, especially due to the increase in the different ethnic groups that live in Spain [28]. In fact, there are few studies on the immigrant population in Spain.

Many of the participants did not agree that GH stimulation was decisive for their diagnosis. However, they considered this test to be of greater value in ruling out a deficit than in confirming it, i.e., it has greater specificity than sensitivity. There are studies in which a level below $3 \mathrm{ng} /$ $\mathrm{ml}$ may correlate with severe deficits [1]. However, despite new laboratory techniques, no exact cut-off point has been established. Lack of uniformity in the criteria to establish the usefulness and indication of stimulation tests, as well as the cut-off level necessary to diagnose a GH deficit, has been pointed out by various authors internationally [29-31]. Stimulation tests remain valid for diagnosis of GH deficit, but one must consider that the measured GH concentration varies depending on the type of test used and the immunoassay employed, so they must be interpreted together with the patient's auxology. 
In any case, in general, the study of GH deficiency should be considered in all pathologies with an alteration in growth velocity that cannot be explained for any other reason.

Gonadal steroid priming to establish the diagnosis in prepubertal ages remains a controversial topic. There is little evidence in studies that support its use, since the group of patients analysed is small and the patients included have different characteristics in terms of chronological age, auxology, and pubertal development. The absence of large, homogenous series in terms of the patients' characteristics would explain why just $30-40 \%$ of paediatric endocrinologists use it before studying GH secretion. In any case, it must be performed and interpreted on an individual basis $[1,32,33]$.

With regard to reassessment of $\mathrm{GH}$ deficit in adolescence when adult stature is reached, $74 \%$ of the experts considered that reassessment is not necessary in cases of isolated $\mathrm{GH}$ deficit with levels of IGF-I within normality. This finding contrasts with a Delphi study performed by the Italian Endocrinology Society in which there is consensus regarding the need for reassessment of these patients [34].

In summary, diagnosis of a GH deficit in childhood and adolescence should be based on a combination of factors that include auxology, and radiological and laboratory evaluation, together with clinical experience [35].

\section{Block 2: small-for-gestational-age patient}

Birth length or birth weight was considered to be the most indispensable criteria for initiating GH treatment in SGA children. However, it was clarified that cases in which this is not known need to be individualised. Furthermore, although it was agreed that parental mean stature could be a criterion for initiating treatment, it was argued that it should not be a limiting factor for initiating treatment in SGA children who meet all other inclusion criteria and Silver-Russell syndrome should not be an exclusion criterion for initiating $\mathrm{GH}$ treatment $[36,37]$. The lack of consensus on the appropriate age to initiate $\mathrm{GH}$ treatment may be due to the lack of evidence of superiority of response for early initiation of treatment. Even so, it has been reported that $90 \%$ of SGA children can experience a catch-up growth spurt that mostly takes place in the first 12 months of life and is completed by 2 years of age, reaching a stature greater than -2 SD [38, 39].

\section{Block 3: GH treatment}

To monitor adverse events arising from GH treatment, in addition to thyroid function tests, bone age, and IGF-I levels, the need to check carbohydrate metabolism was identified, with lipid metabolism being less important [33]. However, other tests to be performed on an individual basis were also mentioned, such as orthopaedic examinations and fundus evaluation due to clinically suggested suspicion of endocranial hypertension, etc.

The response to $\mathrm{GH}$ treatment can be assessed with the increase in stature and growth velocity, expressed in SD or $\mathrm{cm} /$ years [40]. The response in the first year of treatment is considered very important due to its high predictive value for gain in adult stature [41]. It was proposed to assess patients' quality of life as an important response parameter, although its quantification may be heterogeneous due to the fact that standardised quality-of-life questionnaires for children with short stature are rarely used in clinical practice.

$67 \%$ of respondents would initiate $\mathrm{GH}$ treatment in children with Prader-Willi syndrome before the age of 2 years, since it has been shown that GH is safe at that age [42]. It is essential to have contact with expert centres with greater experience that can assist in the use of GH in these patients.

There is lack of consensus on the waiting time before administering $\mathrm{GH}$ in a child with a deficit in oncological remission

\section{Block 4: treatment adherence}

Treatment adherence conditions the response and efficacy of the treatment and is a common problem in all chronic diseases that require maintained treatment [43]. Poor adherence implies a loss of stature, but there are very few studies that have quantified this and it continues to be discussed whether the degree of adherence differs according to the indication [44]. In the case of a non-responder patient, the attitude chosen first is to check treatment adherence. To monitor adherence, the most valued resource was the electronic record, although it was made clear that this should not replace health education, but it is evident that the same degree of objectivity cannot be achieved through any other method. However, the indications for use in the drug's technical data sheet should be taken into account.

Given the importance of the child's self-esteem for good treatment adherence, this should be measured and recorded as a parameter through scales validated for this purpose, although they are rare in clinical practice.

\section{Limitations of the study}

Meetings of experts are, per se, a limitation in terms of the level of evidence. However, out of the more than 200 members of the SEEP, the members with more than 10 year experience in using $\mathrm{GH}$ were selected.

The participation of members from a country with a predominantly publicly financed health system is another of the study's limitations. 


\section{Conclusions and future prospects}

With regard to the implications for everyday clinical practice, and in spite of the heterogeneity of some topics, this study will provide novice paediatric endocrinologists with a guide for critical decisions on the use of GH in childhood.

In terms of future research, it is necessary to verify our results with a larger sample with the participation of experts from other countries, which is expected to reinforce the recommendations of this group of experts.

The variability in the results reflects aspects in which there is not clear consensus yet, which offers new hypotheses to assess.

Supplementary Information The online version contains supplementary material available at https://doi.org/10.1007/s40618-021-01696-0.

Acknowledgements The authors would like to thank all of the participants in the panel of experts (ANNEX), Méderic Ediciones for help with the design and coordination, and Fernando Sánchez Barbero, $\mathrm{PhD}$ for support in writing this manuscript. And special thanks to Fundación Merck Salud for funding and sponsoring the project and developing the paper.

Author contributions RCC has participated in designing the study, developing questions and hypotheses, analysing the information, and drafting the discussion and conclusions. CFR has participated in designing the study, developing questions and hypotheses, analysing the information, and drafting the discussion and conclusions. IGC has participated in designing the study, developing questions and hypotheses, analysing the information, and drafting the discussion and conclusions. FMM has participated in designing the study, developing questions and hypotheses, analysing the information, and drafting the discussion and conclusions. JPLS has participated in designing the study, developing questions and hypotheses, analysing the information, and drafting the discussion and conclusions. JILA has participated in designing the study, developing questions and hypotheses, analysing the information, and drafting the discussion and conclusions.

Funding This study was funded by Fundación Merck Salud.

Availability of data and materials Not applicable.

Code availability Not applicable.

\section{Declarations}

Conflict of interest RCC has no conflicts of interest to declare. She received funds as a consultant from Fundación Merck Salud for this paper. CFR has no conflicts of interest to declare. She received funds as a consultant from Fundación Merck Salud for this paper. IGC has no conflicts of interest to declare. She received funds as a consultant from Fundación Merck Salud for this paper. FMM has no conflicts of interest to declare. She received funds as a consultant from Fundación Merck Salud for this paper. JPLS has no conflicts of interest to declare. He received funds as a consultant from Fundación Merck Salud for this paper. JILA has no conflicts of interest to declare. He received funds as a consultant from Fundación Merck Salud for this paper.

Ethics approval Not applicable.
Consent to participate The panellists were invited to participate in the study by e-mail, informing them of the nature of the study through a presentation letter. Those who responded to the e-mail gave their consent to participate in the study.

Consent for publication All authors of this work provided consent. The panel of participating experts were informed and gave their consent for publication of the results of the consensus.

Open Access This article is licensed under a Creative Commons Attribution 4.0 International License, which permits use, sharing, adaptation, distribution and reproduction in any medium or format, as long as you give appropriate credit to the original author(s) and the source, provide a link to the Creative Commons licence, and indicate if changes were made. The images or other third party material in this article are included in the article's Creative Commons licence, unless indicated otherwise in a credit line to the material. If material is not included in the article's Creative Commons licence and your intended use is not permitted by statutory regulation or exceeds the permitted use, you will need to obtain permission directly from the copyright holder. To view a copy of this licence, visit http://creativecommons.org/licenses/by/4.0/.

\section{References}

1. Collett-Solberg PF, Ambler G, Backeljauw PF, Bidlingmaier M, Biller BMK, Boguszewski MCS et al (2019) Diagnosis, genetics, and therapy of short stature in children: a growth hormone research society international perspective. Horm Res Paediatr 92(1):1-14. https://doi.org/10.1159/000502231

2. Growth Hormone Research Society (2000) Consensus guidelines for the diagnosis and treatment of growth hormone $(\mathrm{GH})$ deficiency in childhood and adolescence: summary statement of the GH Research Society. GH Research Society. J Clin Endocrinol Metab 85(11):3990-3993. https://doi.org/10.1210/jcem.85.11. 6984

3. Barstow C, Rerucha C (2015) Evaluation of short and tall stature in children. Am Fam Physician 92(1):43-50

4. Mericq V, Linares J, Riquelme J (2013) Talla baja: enfoque diagnóstico y bases terapéuticas. Rev Med Clin Condes 24(5):847-856

5. Cohen P, Rogol AD, Deal CL, Saenger P, Reiter EO, Ross JL et al (2008) Consensus statement on the diagnosis and treatment of children with idiopathic short stature: a summary of the Growth Hormone Research Society, the Lawson Wilkins Pediatric Endocrine Society, and the European Society for Paediatric Endocrinology Workshop. J Clin Endocrinol Metab 93(11):4210-4217. https://doi.org/10.1210/jc.2008-0509

6. Hernández M, Castellet J, Narvaiza JL, Rincón JM, Ruiz I, Sánchez E et al (1988) Curvas y tablas de crecimiento. In: Hernández Rodríguez M (ed) Instituto de Investigación sobre Crecimiento y Desarrollo. Fundación Faustino Orbegozo, Bilbao

7. Natale V, Rajagopalan A (2014) Worldwide variation in human growth and the World Health Organization growth standards: a systematic review. BMJ Open 4(1):e003735. https://doi.org/10. 1136/bmjopen-2013-003735

8. World Health Organization Child growth standards. https://www. who.int/toolkits/child-growth-standards. Accessed 31 Mar 2021

9. Fitch K, Bernstein SJ, Aguilar MD, Burnand B, LaCalle JR, Lázaro P, et al. The RAND/UCLA Appropriateness Method User's Manual. http://www.rand.org/pubs/monograph_reports/ MR1269.html. Accessed 31 Mar 2021 
10. Jones J, Hunter D (1995) Consensus methods for medical and health services research. BMJ 311(7001):376-380. https://doi.org/ 10.1136/bmj.311.7001.376

11. Grote FK, Oostdijk W, de Muinck Keizer-Schrama SM, Dekker FW, Verkerk PH, Wit JM (2005) Growth monitoring and diagnostic work-up of short stature: an international inventorization. J Pediatr Endocrinol Metab 18(11):1031-1038. https://doi.org/10. 1515/jpem.2005.18.11.1031

12. Oostdijk W, Grote FK, de Muinck Keizer-Schrama SM, Wit JM (2009) Diagnostic approach in children with short stature. Horm Res 72(4):206-217. https://doi.org/10.1159/000236082

13. Savage MO, Backeljauw PF, Calzada R, Cianfarani S, Dunkel L, Koledova E et al (2016) Early detection, referral, investigation, and diagnosis of children with growth disorders. Horm Res Paediatr 85(5):325-332. https://doi.org/10.1159/000444525

14. Sisley S, Trujillo MV, Khoury J, Backeljauw P (2013) Low incidence of pathology detection and high cost of screening in the evaluation of asymptomatic short children. J Pediatr 163(4):1045-1051. https://doi.org/10.1016/j.jpeds.2013.04.002

15. Savendahl L, Davenport ML (2000) Delayed diagnoses of Turner's syndrome: proposed guidelines for change. J Pediatr 137(4):455-459. https://doi.org/10.1067/mpd.2000.107390

16. Massa G, Verlinde F, De Schepper J, Thomas M, Bourguignon JP, Craen M et al (2005) Trends in age at diagnosis of Turner syndrome. Arch Dis Child 90(3):267-268. https://doi.org/10. 1136/adc.2004.049817

17. Saari A, Sankilampi U, Hannila ML, Saha MT, Makitie O, Dunkel L (2012) Screening of turner syndrome with novel auxological criteria facilitates early diagnosis. J Clin Endocrinol Metab 97(11):E2125-2132. https://doi.org/10.1210/jc.2012-1739

18. Stochholm K, Juul S, Juel K, Naeraa RW, Gravholt CH (2006) Prevalence, incidence, diagnostic delay, and mortality in Turner syndrome. J Clin Endocrinol Metab 91(10):3897-3902. https:// doi.org/10.1210/jc.2006-0558

19. Duche L, Trivin C, Chemaitilly W, Souberbielle JC, Breart G, Brauner R et al (2008) Selecting short-statured children needing growth hormone testing: derivation and validation of a clinical decision rule. BMC Pediatr 8:29. https://doi.org/10.1186/ 1471-2431-8-29

20. Saari A, Harju S, Makitie O, Saha MT, Dunkel L, Sankilampi U (2015) Systematic growth monitoring for the early detection of celiac disease in children. JAMA Pediatr 169(3):e1525. https:// doi.org/10.1001/jamapediatrics.2015.25

21. van Dommelen P, Grote FK, Oostdijk W, Keizer-Schrama SM, Boersma B, Damen GM et al (2008) Screening rules for growth to detect celiac disease: a case-control simulation study. BMC Pediatr 8:35. https://doi.org/10.1186/1471-2431-8-35

22. Cianfarani S, Tondinelli T, Spadoni GL, Scire G, Boemi S, Boscherini B (2002) Height velocity and IGF-I assessment in the diagnosis of childhood onset GH insufficiency: do we still need a second GH stimulation test? Clin Endocrinol (Oxf) 57(2):161-167. https://doi.org/10.1046/j.1365-2265.2002. 01591.X

23. Shen Y, Zhang J, Zhao Y, Yan Y, Liu Y, Cai J (2015) Diagnostic value of serum IGF-1 and IGFBP-3 in growth hormone deficiency: a systematic review with meta-analysis. Eur J Pediatr 174(4):419-427. https://doi.org/10.1007/s00431-014-2406-3

24. Hauer NN, Popp B, Schoeller E, Schuhmann S, Heath KE, Hisado-Oliva A et al (2018) Clinical relevance of systematic phenotyping and exome sequencing in patients with short stature. Genet Med 20(6):630-638. https://doi.org/10.1038/gim. 2017.159

25. Carrascosa A, Fernández JM, Ferrández A, López-Siguero JP, Sánchez E (2008) Estudio Transversal Español de Crecimiento 2008. Hercu, Barcelona
26. López de Lara D, Santiago Paniagua P, Tapia Ruiz M, Rodríguez Mesa MD, Gracia Bouthelier R, Carrascosa LA (2010) Valoración del peso, talla e IMC en niños, adolescentes y jóvenes de la Comunidad Autónoma de Madrid. An Pediatr (Barc) 73(6):305-319

27. Millennial's Growth. Estudio Longitudinal de Crecimiento Barcelona 1995-2017. http://www.millennialsgrowth.com/. Accessed 31 Mar 2021

28. Sánchez González E, Carrascosa Lezcano A, Fernández García JM, Fernández Longás A, López de Lara D, López-Siguero JP (2011) Estudios españoles de crecimiento: situación actual, utilidad y recomendaciones de uso. An Pediatr (Barc) 74(3):193. e191-e116

29. Juul A, Bernasconi S, Clayton PE, Kiess W, DeMuinck-Keizer SS, Drugs S et al (2002) European audit of current practice in diagnosis and treatment of childhood growth hormone deficiency. Horm Res 58(5):233-241. https://doi.org/10.1159/00006 6265

30. Binder G, Reinehr T, Ibanez L, Thiele S, Linglart A, Woelfle J et al (2019) GHD diagnostics in Europe and the US: an audit of national guidelines and practice. Horm Res Paediatr 92(3):150 156. https://doi.org/10.1159/000503783

31. Chesover AD, Dattani MT (2016) Evaluation of growth hormone stimulation testing in children. Clin Endocrinol (Oxf) 84(5):708-714. https://doi.org/10.1111/cen.13035

32. Grimberg A, DiVall SA, Polychronakos C, Allen DB, Cohen LE, Quintos JB et al (2016) Guidelines for growth hormone and insulin-like growth factor-I treatment in children and adolescents: growth hormone deficiency, idiopathic short stature, and primary insulin-like growth factor-I deficiency. Horm Res Paediatr 86(6):361-397. https://doi.org/10.1159/000452150

33. Murray PG, Dattani MT, Clayton PE (2016) Controversies in the diagnosis and management of growth hormone deficiency in childhood and adolescence. Arch Dis Child 101(1):96-100. https://doi.org/10.1136/archdischild-2014-307228

34. Aimaretti G, Attanasio R, Cannavo S, Nicoletti MC, Castello R, Di Somma C et al (2015) Growth hormone treatment of adolescents with growth hormone deficiency (GHD) during the transition period: results of a survey among adult and paediatric endocrinologists from Italy. Endorsed by SIEDP/ISPED, AME, SIE, SIMA. J Endocrinol Invest 38(3):377-382. https://doi.org/ 10.1007/s40618-014-0201-7

35. Collett-Solberg PF, Jorge AAL, Boguszewski MCS, Miller BS, Choong CSY, Cohen P et al (2019) Growth hormone therapy in children; research and practice-a review. Growth Horm IGF Res 44:20-32. https://doi.org/10.1016/j.ghir.2018.12.004

36. Lem AJ, de Kort SW, de Ridder MA, Hokken-Koelega AC (2010) Should short children born small for gestational age with a distance to target height $<1$ standard deviation score be excluded from growth hormone treatment? Clin Endocrinol (Oxf) 73(3):355-360. https://doi.org/10.1111/j.1365-2265. 2010.03833.x

37. Wakeling EL, Brioude F, Lokulo-Sodipe O, O'Connell SM, Salem J, Bliek J et al (2017) Diagnosis and management of Silver-Russell syndrome: first international consensus statement. Nat Rev Endocrinol 13(2):105-124. https://doi.org/10. 1038/nrendo.2016.138

38. Clayton PE, Cianfarani S, Czernichow P, Johannsson G, Rapaport R, Rogol A (2007) Management of the child born small for gestational age through to adulthood: a consensus statement of the International Societies of Pediatric Endocrinology and the Growth Hormone Research Society. J Clin Endocrinol Metab 92(3):804-810. https://doi.org/10.1210/jc.2006-2017

39. Ibáñez Toda L, Grupo para el Estudio del Niño Pequeño para la Edad Gestacional de la Sociedad Española de Endocrinología Pediátrica (2018) Pequeño para la edad gestacional: 
consecuencias endocrino-metabólicas. In: Asociación Española de Pediatría de Atención Primaria (ed) Curso de actualización pediatría 2018. Lúa Ediciones 3.0, Madrid, pp 179-190

40. Bang P, Bjerknes R, Dahlgren J, Dunkel L, Gustafsson J, Juul A et al (2011) A comparison of different definitions of growth response in short prepubertal children treated with growth hormone. Horm Res Paediatr 75(5):335-345. https://doi.org/10. $1159 / 000322878$

41. Bang P, Ahmed SF, Argente J, Backeljauw P, Bettendorf M, Bona $G$ et al (2012) Identification and management of poor response to growth-promoting therapy in children with short stature. Clin Endocrinol (Oxf) 77(2):169-181. https://doi.org/ 10.1111/j.1365-2265.2012.04420.x

42. Deal CL, Tony M, Hoybye C, Allen DB, Tauber M, Christiansen JS et al (2013) Growth Hormone Research Society workshop summary: consensus guidelines for recombinant human growth hormone therapy in Prader-Willi syndrome. J Clin Endocrinol Metab 98(6):E1072-1087. https://doi.org/10.1210/jc.2012-3888

43. Cutfield WS, Derraik JG, Gunn AJ, Reid K, Delany T, Robinson E et al (2011) Non-compliance with growth hormone treatment in children is common and impairs linear growth. PLoS ONE 6(1):e16223. https://doi.org/10.1371/journal.pone.0016223

44. de Arriba MA, Muñiz VC, Saez JJA, Beisti A, Llovet E, Aizpun JIL (2021) Impact of adherence on growth response during the first 2 years of growth hormone treatment. Endocrine 72(2):513523. https://doi.org/10.1007/s12020-020-02560-6

Publisher's Note Springer Nature remains neutral with regard to jurisdictional claims in published maps and institutional affiliations. 